\title{
PENERAPAN REALISTIC MATHEMATIC EDUCATION (RME) MENINGKATKAN HASIL BELAJAR MATEMATIKA SISWA KELAS VI SD
}

\author{
Astuti \\ ${ }^{1}$ Universitas Pahlawan Tuanku Tambusai Prodi Pendidikan Matematika Jln Tuanku Tambusai nomor 23 \\ astutimasnur@gmail..com
}

\begin{abstract}
The background of the problem in this study is the students easily forget the material taught and less well understood the concept because the concept of the material for children less attention. In the RME approach it emphasizes the importance of the real context that students know and the construction process of mathematical knowledge by the students themselves so that the concepts received by students are more meaningful. This research is in the form of Classroom Action Research (PTK) with the subject of the study of grade VI SDIT Raudhaturrahmah Pekanbaru academic year 2013/2014. The purpose of this research is to improve the mathematics learning outcomes of students of class VI SDIT Raudhaturrahmah Pekanbaru on the matter of fractional counting operations. The data in this study is quantitative data obtained from the test of knowledge and understanding of students through daily test. The results of this study indicate that the average percentage of teacher activity in cycle I is $85.22 \%$ (Category: Very Good) and in cycle II is $93.18 \%$ (Category: Very Good). While the percentage of student activity activity in cycle I is 70,5\% (Category: Enough) and increase to 86,3\% (Category: Good) in cycle II. The average of the students' learning outcomes on the basic score was 69.2 increased to 92.1 in cycle I and increased again to 95.9 in cycle II. While classical mastery in cycle I and cycle II is reached. This means that the application of realistic mathematics education approach can improve the learning outcomes of students of grade VI SDIT Raudhaturrahmah Pekanbaru.
\end{abstract}

Keywords: Realistic Mathematic Education, increase, result of mathematics learning

\begin{abstract}
Abstrak
Latar belakang masalah dalam penelitian ini adalah siswa mudah lupa dengan materi yang diajarkan dan kurang memahami konsep dengan baik karena konsep materi bagi anak kurang diperhatikan. Dalam pendekatan RME ini menekankan akan pentingnya konteks nyata yang dikenal siswa dan proses konstruksi pengetahuan matematika oleh siswa sendiri sehingga konsep yang diterima siswa lebih bermakna. Penelitian ini dalam bentuk Penelitian Tindakan Kelas (PTK) dengan subjek penelitian siswa kelas VI SDIT Raudhaturrahmah Pekanbaru tahun ajaran 2013/2014. Tujuan dalam penelitian ini adalah untuk meningkatkan hasil belajar matematika siswa kelas VI SDIT Raudhaturrahmah Pekanbaru pada materi operasi hitung pecahan. Data dalam penelitian ini adalah data kuantitatif yang diperoleh dari tes pengetahuan dan pemahaman siswa melalui ulangan harian. Hasil penelitian ini menunjukkan bahwa rata-rata persentase aktivitas guru pada siklus I adalah 85,22\% (Kategori: Amat Baik) dan pada siklus II adalah 93,18\% (Kategori: Amat Baik). Sedangkan persentase aktivitas belajar siswa pada siklus I adalah 70,5\% (Kategori: Cukup) dan meningkat menjadi 86,3\% (Kategori: Baik) pada siklus II. Rata-rata hasil belajar siswa pada skor dasar adalah 69,2 meningkat menjadi 92,1 pada siklus I dan meningkat lagi menjadi 95,9 pada siklus II. Sedangkan ketuntasan klasikal pada siklus I dan siklus II tercapai. Ini artinya bahwa penerapan pendekatan pendidikan matematika realistik dapat meningkatkan hasil belajar matematika siswa kelas VI SDIT Raudhaturrahmah Pekanbaru.
\end{abstract}

Kata kunci: Realistic Mathematic Education, Meningkatkan, Hasil Belajar Matematika Siswa

Matematika merupakan ilmu pengetahuan universal yang mendasari perkembangan teknologi modern, mempunyai peran penting dalam berbagai disiplin ilmu dan dapat melatih daya pikir manusia. Sesuai dengan fungsinya, pembelajaran matematika bertujuan untuk menghitung, mengukur, dan menggunakan rumus-rumus matematika yang diperlukan dalam kehidupan sehari-hari.

Tujuan pembelajaran matematika di Sekolah Dasar GBPP (Garis-garis Besar Program Pengajaran) secara umum adalah: 1) Mempersiapkan siswa agar mampu menghadapi perubahan yang 
ada di dalam kehidupan dan di dunia yang selalu berkembang melalui latihan atas dasar pemikiran secara logis, rasional, kritis, cermat, jujur, dan efektif. 2) Mempersiapkan siswa agar dapat menggunakan matematika dan pola pikir matematika dalam kehidupan sehari-hari dan dalam mempelajari berbagi ilmu pengetahuan. 3) Memecahkan masalah yang meliputi kemampuan memahami masalah, merancang model matematika, menyelesaikan model dan menafsirkan solusi yang diperoleh. 4) Mengkomunikasikan gagasan dengan simbol, tabel, diagram, atau media lain untuk memperjelas keadaan atau masalah. 5) Memiliki sikap menghargai kegunaan matematika dalam kehidupan, yaitu memiliki rasa ingin tahu, perhatian dan minat dalam mempelajari matematika, serta sikap ulet dan percaya diri dalam memcahkan masalah.

Sementara tujuan pembelajaran matematika di Sekolah Dasar (GBPP) secara khusus adalah: 1) Menumbuhkan dan mengembangkan keterampilan berhitung sebagai alat dalam kehidupan seharihari. 2) Menumbuhkan kemampuan siswa, yang dapat dialihgunakan melalui kegiatan matematika. 3) Mengembangkan kemampuan dasar matematika sebagai bekal belajar lebih lanjut di SLTP. 4) Membentuk sikap logis, kritis, kreatif, cermat dan disiplin.

Pada kenyataannya banyak kita dengar keluhan siswa tehadap matematika bahwa matematika membuat siswa bingung (dan juga orang tuanya) bahkan dianggap sebagai hal yang menakutkan oleh sebagian siswa. Begitu beratnya peran dan tanggungjawab guru matematika yang membuat kekhawatiran siswa pada prestasi belajarnya. Faktor lain yang juga ikut mempengaruhi rasa bosan pada matematika adalah faktor penyampaian materi atau metode pembelajaran matematika yang kurang bervariasi. Hal ini jelas sangat berakibat buruk bagi perkembangan pendidikan matematika. Oleh karena itu, perubahan proses pembelajaran matematika yang menyenangkan harus menjadi prioritas utama. Hasil empiris di atas jelas merupakan suatu permasalahan yang merupakan faktor penting dalam mewujudkan tujuan pembelajaran matematika sesuai yang diamanatkan dalam kurikulum pendidikan matematika.

Salah satu faktor penyebab rendahnya pemahaman siswa terhadap konsep-konsep matematika adalah pola pembelajaran yang dilaksanakan oleh guru. Pembelajaran matematika di Indonesia dewasa ini, "dunia nyata" hanya digunakan untuk mengaplikasikan konsep dan kurang mematematisasi "dunia nyata". Bila dalam pembelajaran di kelas, pengalaman anak sehari-hari dijadikan inspirasi penemuan dan pengkonstruksian konsep (pematematisasian pengalaman seharihari) dan mengaplikasikan kembali ke "dunia nyata" maka anak akan mengerti konsep dan dapat melihat manfaat matematika (I Gusti Putu Suharta, 2001).

Kebanyakan proses pembelajaran yang digunakan oleh guru adalah pembelajaran konvensional yakni ceramah, tanya jawab dan pemberian tugas. Dalam hal ini, proses pembelajaran didominasi oleh guru. Oleh karena itu, pendekatan pembelajaran tersebut perlu segera diubah.

Berdasarkan permasalahan tersebut, mengingat bahwa untuk tahun pelajaran 2014/2015 masih dengan KKM yang sama yaitu 77 maka perlu dicari suatu pendekatan yang dapat mendukung proses pembelajaran matematika yang menyenangkan dan bukan menyeramkan sehingga dapat 
meningkatkan motivasi sekaligus mempermudah pemahaman siswa dalam belajar matematika dengan demikian hasil belajar siswa pun bisa meningkat (tercapai KKM). Salah satu pendekatan pembelajaran matematika saat ini yang dapat diterapkan adalah Rrealistic Mathematics Education $(R M E)$. $R M E$ ini sesuai dengan perubahan paradigma pembelajaran, yaitu dari paradigma mengajar ke paradigma belajar atau perubahan paradigma pembelajaran yang berpusat pada guru ke paradigma pembelajaran yang berpusat pada siswa. Hal ini adalah salah satu upaya dalam rangka memperbaiki mutu pendidikan matematika.

Melalui $R M E$ yang pengajarannya berangkat dari persoalan dalam dunia nyata, diharapkan pelajaran tersebut menjadi bermakna bagi siswa. Dengan demikian siswa termotivasi untuk terlibat dalam pelajaran. Untuk mendukung proses pembelajaran yang mengaktifkan siswa diperlukan suatu pengembangan materi pelajaran matematika yang difokuskan kepada aplikasi dalam kehidupan sehari-hari (kontekstual) dan disesuaikan dengan tingkat kognitif siswa, serta penggunaan metode evaluasi yang terintegrasi pada proses pembelajaran.

Dalam $R M E$ siswa didorong atau ditantang untuk aktif belajar, bahkan diharapkan dapat mengkonstruksi atau membangun sendiri pengetahuan yang diperolehnya (Dalyana, 2003:17). Berdasarkan pemikiran tersebut, maka penulis mencoba melakukan penelitian yang berjudul: "Penenerapan Pendekatan RME untuk Meningkatkan Hasil Belajar Matematika Siswa Kelas VI SDIT Raudhaturrahmah Pekanbaru”.

\section{Pengertian Realistic Mathematics Education (RME)}

Realistic Mathematics Education (RME) dikembangkan berdasarkan pemikiran Hans Freudenthal (1905 - 1990) seorang penulis, pendidik, dan matematikawan berkebangsaan Jerman/Belanda yang berpendapat bahwa "matematika merupakan aktivitas insani (human activities) dan harus dikaitkan dengan realitas". Berdasarkan pemikiran tersebut, $R M E$ mempunyai ciri antara lain, bahwa dalam proses pembelajaran siswa harus diberikan kesempatan untuk menemukan kembali (to reinvent) matematika melalui bimbingan guru (Gravemeijer, 1994), dan bahwa penemuan kembali (reinvention) ide dan konsep matematika tersebut harus dimulai dari penjelajahan berbagai situasi dan persoalan "dunia riil”" (de Lange, 1995).

Ruseffendi (2001) berpendapat bahwa untuk membudayakan berpikir ilmiah serta bersikap kritis dan kreatif proses pembelajaran dapat dilakukan dengan pendekatan realistik. Selanjutnya dikatakan, jika kita (guru) rajin memperhatikan lingkungan dan mengaitkan pembelajaran dengan lingkungan maka besar kemungkinan berpikir ilmiah siswa itu akan tumbuh. Oleh karena itu, materi harus dipilih dan disesuaikan dengan lingkungan yang berkaitan dengan kehidupan sehari-hari (kontekstual) dan tingkat kognitif siswa, dimulai dengan cara-cara informal melalui pemodelan sebelum dengan cara formal. Hal ini sesuai dengan karakteristik $R M E$. Ide utama dari $R M E$ adalah bahwa siswa harus diberi kesempatan untuk menemukan kembali (reinvent) ide dan konsep 
matematika dengan bimbingan orang dewasa melalui penjelajahan berbagai situasi dan persoalanpersoalan dunia nyata atau real world (Gravemeijer, 1994).

Matematika tidak disajikan dalam bentuk hasil jadi (a ready-made product), tetapi siswa harus belajar menemukan kembali konsep-konsep matematika. Siswa membentuk sendiri konsep dan prosedur matematika melalui penyelesaian soal yang realistik dan kontekstual. Hal ini sesuai dengan pandangan teori constructivism yang menyatakan bahwa pengetahuan matematika tidak dapat diajarkan oleh guru, melainkan harus dibangun sendiri oleh siswa (Cobb dalam Armanto, 2001).

Soal kontekstual (context problem) dimaksudkan untuk menopang terlaksananya suatu proses penemuan kembali (reinvention) yang memberi peluang bagi siswa untuk secara formal memahami matematika (Gravemeijer, 1994, Subandar, 2001). Oleh karena itu, matematika harus dekat dengan siswa dan relevan dengan situasi kehidupan sehari-hari. Jadi, $R M E$ pada dasarnya adalah pemanfaatan realitas dan lingkungan yang dipahami peserta didik untuk memperlancar proses pembelajaran matematika, sehingga mencapai tujuan pendidikan matematika lebih baik. Realita yang dimaksud yaitu hal-hal yang nyata atau kongret yang dapat diamati atau dipahami peserta didik lewat membayangkan, sedangkan yang dimaksud dengan lingkungan adalah lingkungan tempat peserta didik berada baik lingkungan sekolah, keluarga maupun masyarakat yang dapat dipahami peserta didik. Lingkungan dalam hal ini disebut juga kehidupan sehari-hari.

$R M E$ menggunakan masalah kontekstual (contextual problems) sebagai titik tolak dalam belajar matematika. Perlu dicermati bahwa suatu hal yang bersifat kontekstual dalam lingkungan siswa di suatu daerah, belum tentu bersifat konteks bagi siswa di daerah lain. Contoh berbicara tentang kereta api, merupakan hal yang konteks bagi siswa yang ada di pulau Jawa, namun belum tentu bersifat konteks bagi siswa di luar Jawa. Oleh karena itu pembelajaran matematika dengan pendekatan realistik harus disesuaikan dengan keadaan daerah tempat siswa berada.

Masalah dalam pembelajaran matematika merupakan suatu "keharusan" dalam menghadapi dunia yang tidak menentu. Siswa perlu dipersiapkan bagaimana mendapatkan dan menyelesaikan masalah. Masalah yang disajikan ke siswa adalah masalah kontekstual yakni masalah yang memang semestinya dapat diselesaikan siswa sesuai dengan pengalaman siswa dalam kehidupannya.

Menurut Gravemeijer (1994) dan Armanto (2002), terdapat tiga prinsip utama dalam $R M E$, yaitu:

a) Penemuan terbimbing dan bermatematika secara progresif (guided reinvention and progressive mathematization);

b) Fenomena pembelajaran (didactical phenomenology); dan

c) Model pengembangan mandiri (self-developed model).

Prinsip penemuan terbimbing berarti bahwa siswa diberi kesempatan untuk menemukan sendiri konsep matematika dengan menyelesaikan berbagai soal kontekstual. Soal kontekstual mengarahkan siswa membentuk konsep, menyusun model, menerapkan konsep yang telah diketahui, dan menyelesaikannya berdasarkan kaidah matematika yang berlaku. 
Dari prinsip di atas diperoleh kesimpulan bahwa $R M E$ secara garis besar memiliki lima karakteristik (De Lange, 1996; Treffers, 1991; Gravemeijer, 1994; Darhim, 2004), yaitu:

(1) Menggunakan masalah kontekstual sebagai peluang bagi aplikasi dan sebagai titik tolak dari mana suatu konsep matematika yang diinginkan dapat muncul;

(2) Menggunakan model atau jembatan dengan instrumen vertikal dengan perhatian diarahkan pada pengenalan model, skema, dan simbolisasi daripada mentransfer rumus atau matematika formal secara langsung;

(3) Menggunakan kontribusi siswa dengan kontribusi yang besar pada proses pembelajaran datang dari siswa sendiri di mana mereka dituntut dari cara-cara informal ke arah yang formal;

(4) Terjadinya interaktivitas dalam proses pembelajaran di mana negosiasi secara eksplisit, intervensi kooperasi, dan evaluasi sesama siswa dan guru adalah faktor penting dalam proses pembelajaran secara konstruktif dengan menggunakan strategi informal sebagai jantung untuk mencapai formal; dan

(5) Menggunakan berbagai teori belajar yang relevan, saling terkait, dan terintegrasi dengan topik pembelajaran lainnya. Pendekatan holistik menunjukkan bahwa unit-unit belajar tidak akan dapat dicapai secara terpisah, tetapi keterkaitan dan keterintegrasian harus diwujudkan dalam pemecahan masalah.

\section{Tujuan $R M E$}

Mengaitkan pembelajaran matematika yang abstrak dengan dikehidupan nyata agar matematika mudah dipahami. Ruseffendi (1979) menyarankan agar dalam menerangkan pengerjaan hitung sedapat mungkin supaya dimulai dengan menggunakan benda-benda real, gambarnya atau diagramnya yang ada kaitannya dengan kehidupan nyata sehari-hari. Kemudian dilanjutkan ke tahap kedua yaitu berupa modelnya dan akhirnya ke tahap simbol. Agar pembelajaran mudah diterima siswa.

\section{Strategi pembelajaran matematika dengan RME}

Pengajaran matematika dengan RME meliputi aspek-aspek berikut (De Lange, 1995):

a) Memulai pelajaran dengan mengajukan masalah (soal) yang "riil" bagi siswa sesuai dengan pengalaman dan tingkat pengetahuannya, sehingga siswa segera terlibat dalam pelajaran secara bermakna;

b) Permasalahan yang diberikan tentu harus diarahkan sesuai dengan tujuan yang ingin dicapai dalam pelajaran tersebut;

c) Siswa mengembangkan atau menciptakan model-model simbolik secara informal terhadap persoalan/masalah yang diajukan;

d) Pengajaran berlangsung secara interaktif: siswa menjelaskan dan memberikan alasan terhadap jawaban yang diberikannya, memahami jawaban temannya (siswa lain), setuju terhadap jawaban 
temannya, menyatakan ketidaksetujuan, mencari alternatif penyelesaian yang lain; dan melakukan refleksi terhadap setiap langkah yang ditempuh atau terhadap hasil pelajaran.

\section{Hasil Belajar}

Untuk mengetahui pengertian hasil belajar kita harus melihat dulu pengertian hasil belajar menurut para ahli seperti berikut:

1. Purwanto (2011:46) hasil belajar adalah perubahan perilaku peserta didik akibat belajar. Perubahan perilaku disebabkan karena dia mencapai penguasaan atas sejumlah bahan yang diberikan dalam proses belajar mengajar. Lebih lanjut lagi ia mengatakan bahwa hasil belajar dapat berupa perubahan dalam aspek kognitif, afektif dan psikomotorik.

2. Sudjana (2003:3) mengemukakan bahwa hasil belajar adalah perubahan tingkah laku yang mencakup bidang kognitif, afektif, dan psikomotorik yang dimiliki oleh siswa setelah menerima pengalaman belajar.

3. Hamalik (2003:155) hasil belajar adalah sebagai terjadinya perubahan tingkah laku pada diri seseorang yang dapat di amati dan di ukur bentuk pengetahuan, sikap dan keterampilan. Perubahan tersebut dapat di artikan sebagai terjadinya peningkatan dan pengembangan yang lebih baik sebelumnya yang tidak tahu menjadi tahu.

Berdasarkan pendapat yang telah dipaparkan di atas, maka dapat dikemukakan bahwa hasil belajar adalah perubahan perilaku pada diri seseorang akibat tindak belajar yang mencakup aspek kognitif, aspek afektif, dan aspek psikomotorik.

Sedangkan menurut Bimo Walgito (1986:124-129) dalam belajar agar dapat mencapai hasil yang sebaik-baiknya maka harus memperhatikan faktor-faktor seperti berikut ini.

1. Faktor anak atau individu yang belajar, yaitu terdiri dari.

a) Faktor fisik

b) Faktor psikhis, antara lain: motif, minat, konsentrasi, natural curiosity, balance personaly (pribadi yang seimbang), self discipline, self confidence, intelegensi, dan ingatan.

2. Faktor lingkungan, antara lain: Tempat, alat-alat untuk belajar, suasana, waktu, pergaulan.

3. Faktor bahan yang dipelajari: belajar secara keseluruhan lebih baik dari pada belajar secara bagian-bagian,

a) sebagai waktu belajar disediakan untuk mengadakan ulangan (receptition),

b) apa yang dipelajari diadakan ualangan sesering mungkin,

c) dalam mengulangi pelajaran hendaknya' sepesial receptition",

d) pergunakan cara neumoteknik (Bimo Walgito, 1986:124-129)

\section{METODE}

Penelitian ini difokuskan pada upaya guru untuk meningkatkan hasil belajar siswa pada mata pelajaran matematika dengan tujuan untuk mengetahui berapa besar model pembelajaran pendekatan matematika realistik yang digunakan dapat meningkat. 
Penelitian tindakan kelas ini akan dilaksanakan di SDIT Raudhaturrahmah Pekanbaru, alasan mengambil lokasi atau tempat ini dengan pertimbangan sekolah tersebut tempat mengajar peneliti, sehingga peneliti lebih mengetahui keadaan siswa yang hendak diteliti, dan mudah dalam mengumpulkan data, serta peluang waktu yang luas dan subyek penlitian yang sangat sesuai dengan target peneliti.

Penelitian ini akan dilakukan dalam dua siklus, yaitu pada tahun pelajaran 2013/2014 semester genap pada bulan Februari sampai dengan Maret 2014.

\section{Desain Penelitian}

Bentuk penelitian ini adalah Penelitian Tindakan Kelas (PTK). Karena peneliti sekaligus guru yang mengajar di kelas yang peneliti teliti. Menurut Arikunto (2008) Penelitian Tindakan Kelas (PTK) dapat didefenisikan sebagai suatu bentuk penelitian yang bersifat reflektif dengan melakukan tindakan tertentu, agar dapat memperbaiki dan meningkatkan praktek pembelajaran di kelas secara profesional.

Menurut Kerlinger yang dikutip Yuli Sulistiyowati P.R (2005:55) desain penelitian adalah rencana dan struktur penyelidikan yang disusun sedemikian rupa sehingga peneliti akan dapat memperoleh jawaban untuk pertanyaan-pertanyaan penelitian.

Desain penelitian yang digunakan dalam penelitian ini adalah desain putaran spiral yang dikembangkan oleh Kemmis \& Mc Taggart (Kasihani Kasbolah, 1998:113). Dalam perencanaan Kemmis \& Mc Taggart menggunakan sistem spiral yang dimulai dengan perencanaan, tindakan, pengamatan, dan refleksi.

Penelitian ini berjalan melalui beberapa siklus. Siklus kedua dilaksanakan apabila siklus pertama belum tercapai sehingga mengulangi kegiatan pertama, dan bila belum berhasil dilanjutkan dengan siklus berikutnya. Pada penelitian ini, rencana pelaksanaan tindakan telah peneliti tetapkan sesuai dengan desain penelitian tersebut. Dalam Penelitian ini, tiap 1 siklus akan dilaksanakan dengan alur sebagai berikut:

1. Perencanaan

a. Peneliti menetapkan materi yang akan disampaikan kepada siswa dengan menggunakan pendekatan RME.

b. Menyususn Rencana Pelaksanaan Pembelajaran (RPP)

c. Membuat Lembar Kerja Siswa (LKS) lengkap dengan media atau alat peraga yang digunakan

d. Menyiapkan lembar pengamatan siswa dan guru

e. Menyususn perangkat evaluasi pembelajaran

2. Tindakan

a. Guru mengkondisikan siswa dalam situasi belajar yang kondusif 
b. Guru menyampaikan apersepsi

c. Guru menyampaikan tujuan pembelajaran dan memotivasi siswa

d. Guru menyampaikan langkah-langkah pembelajaran

e. Siswa diberi LKS beserta alat dan bahan

f. Guru mengajukan masalah kontekstual (terdapat dalam LKS)

g. Siswa secara berkelompok menyelesaikan masalah kontekstual LKS secara informal

h. Siswa melakukan kegiatan selanjutnya yang ada di LKS

i. Guru memotivasi, mengamati dan membimbing kerja siswa

j. Setelah selesai siswa mempresentasikan hasil kerjanya di depan kelas

k. Guru mengenalkan konsep pelajaran dan menjelaskan penyelsaian masalah secara formal

1. Siswa bersama guru menyimpulkan materi pelajaran

m. Guru memberikan tes formatif/evaluasi

3. Observasi

a. Aktifitas siswa dalam pembelajaran

b. Aktifitas guru dalam pembelajaran

4. Refleksi

Meliputi kegiatan analisis hasil pembelajaran dan sekaligus menyusun rencana perbaikan pada siklus berikutnya.

\section{Instrumen Penelitian}

Suharsimi Arikunto dalam buku Manajemen Penelitian (2005:101) mengartikan instrumen penelitian sebagai alat bantu merupakan saran yang dapat diwujudkan dalam benda misalnya angket, daftar cek, pedoman wawancara, lembaran pengamatan. Dalam penelitian ini instrumen yang dipakai antara lain :

Silabus merupakan rencana yang menyatukan kegiatan pembelajaran, pengelolaan kelas dan penelitian hasil belajar di kelas untuk mencapai suatu kompetensi. Silabus tersebut menggambarkan kegiatan yang dilakukan oleh siswa untuk mencapai: standar kompetensi, kompetensi dasar, hasil belajar, indikator, kegiatan pembelajaran, materi, alokasi waktu, sarana dan sumber belajar, serta penilaian

Rencana Pelaksanaan Pembelajaran (RPP) adalah rencana yang menggambar prosedur dan manajemen pembelajaran untuk mencapai satu atau lebih kompetensi dasar yang ditetapkan dalam silabus yang disusun secara sistematis berisikan: standar kompetensi, kompetensi dasar, indikator,, materi ajar, tujuan pembelajran, metode pembelajaran, kegiatan pembelajaran, alat dan bahan, dan penilaian. Lembaran Kerja Siswa (LKS): memuat informasi, materi, langkah kerja, soal-soal yang harus dikerjakan siswa. Instrumen Pengumpulan, Data dikumpulkan: lembar pengamatan aktifitas guru dan siswa dan lembar soal tes. 
Pedoman observasi yang digunakan peneliti yaitu memuat garis besar sejauh mana minat dan sikap positif serta partisipasi siswa dalam proses pembelajaran matematika. Lembar pengamatan digunakan untuk memperoleh data sebelum tindakan, baik dari guru maupun pengamatan langsung di lapangan. Sedangkan lembar soal tes digunakan untuk menguji kemampuan dan prestasi belajar siswa.

\section{HASIL DAN PEMBAHASAN}

Analisis Hasil Tindakan

\section{Aktivitas guru}

Aktivitas guru dalam pembelajaran menggunakan $R M E$ pada pertemuan pertama siklus I sudah berjalan cukup baik meskipun guru masih sulit mengarahkan siswa untuk mengikuti langkahlangkah pembelajaran. Guru agak kesulitan dalam mengkondisikan siswa selama siswa mengerjakan LKS. Pada pertemuan kedua siklus I, aktivitas guru sudah berjalan lebih baik, meskipun guru masih kurang dalam mengelola waktu. Guru tidak membatasi lamanya siswa mengerjakan LKS sehingga berdampak siswa kekurangan waktu ketika mengerjakan evaluasi.

Pada pertemuan pertama dan kedua siklus II proses pembelajaran sudah berjalan dengan baik, guru sudah bisa menguasai kelas, sudah bisa mengkondisikan waktu sehingga tidak terulang lagi siswa pulang terlambat, dan siswa sudah bisa dikondisikan untuk mengerjakan LKS bersama teman sebangkunya dengan lebih tertib.

Berdasarkan data pada tabel di atas terlihat bahwa aktivitas guru pada setiap kali pertemuan semakin meningkat dan mendapatkan kriteria sangat baik. Aktivitas guru selama proses pembelajaran mendapat nilai 3 dan 4 . Ini menunjukkan bahwa peneliti sebagai guru telah melaksanakan setiap langkah-langkah kegiatan dengan baik dan sesuai dengan kompetensi yang diharapkan.

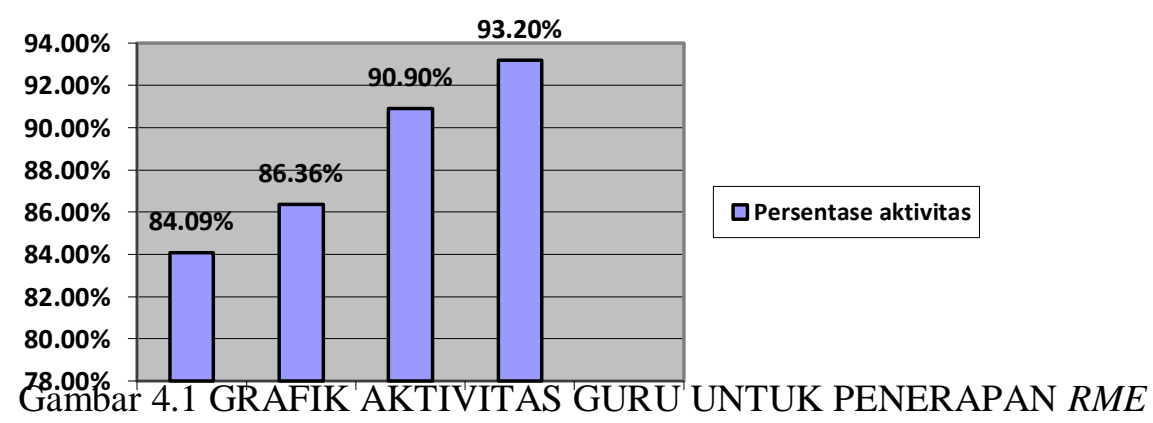

Terjadi peningkatan aktivitas guru pada setiap pertemuan. Pada pertemuan pertama siklus I persentase aktivitas guru adalah $84,09 \%$, pertemuan kedua siklus I persentase aktivitas guru 
meningkat 2,27\% menjadi $86,36 \%$, pertemuan pertama siklus II meningkat 4,54\% menjadi 90,90\%, dan pada pertemuan kedua siklus II aktivitas guru adalah 93,20\%.

\section{Aktivitas Siswa}

Proses pembelajaran pada pertemuan pertama siklus I berjalan sesuai yang direncanakan. Namun siswa masih canggung dengan langkah-langkah pembelajaran yang dilakukan guru, karena pendekatan yang digunakan peneliti merupakan hal yang baru bagi mereka. Siswa menganggap LKS yang diberikan merupakan lembar soal ujian. Harus diberikan penjelasan apa yang harus mereka lakukan meskipun langkah-langkah kegiatan telah diberikan, hal ini dikarenakan siswa yang malas untuk membaca dan memahami perintah yang ada di LKS. Siswa juga suka berjalan ke meja teman yang lain untuk melihat pekerjaan temannya, dan ini membuat temannya terganggu. Namun, menurut pengamat untuk tahap awal sudah baik, hanya saja penguasaan kelas yang harus ditingkatkan agar siswa bisa memperhatikan guru dan mengikuti instruksi yang diberikan. Persentase aktvitas siswa pada pertemuan pertama ini adalah $67,5 \%$.

Kegiatan pembelajaran pada pertemuan kedua siklus I berjalan sesuai dengan yang direncanakan. Siswa sangat antusias ketika mengerjakan LKS dan banyak bertanya bagaimana cara yang benar dalam melaksanakan kegiatan dan sebagian siswa menemui hambatan ketika mereka harus mengisi air $\frac{1}{4}, \frac{1}{3}, \frac{1}{5}$ dan $\frac{2}{3}$. Pengamat mengatakan partisipasi siswa dalam kegiatan pembelajaran sudah meningkat namun masih perlu dimotivasi secara terus menerus untuk menumbuhkan rasa percaya diri siswa untuk mau mempresentasikan hasil kerjanya. Persentase aktivitas siswa pada pertemuan kedua ini adalah $70 \%$.

Pada pertemuan pertama siklus II, proses pembelajaran jauh lebih meningkat, siswa sangat antusias dalam mengerjakan LKS. Siswa sangat bersemangat dalam memecahkan masalah menggunakan media pembelajaran yang diberikan. Namun ketika diminta untuk mempresentasikan hasil kerja, siswa masih perlu dimotivasi. Persentase skor aktivitas siswa pada pertemuan pertama siklus ini adalah $87,5 \%$.

Berdasarkan data pada lembar pengamatan aktivitas siswa pada pertemuan kedua siklus II, proses pembelajaran sudah berjalan dengan baik sesuai dengan rencana pembelajaran. Siswa lebih semangat dan sangat sungguh-sungguh dalam menganalisa soal cerita yang diberikan guru. Tidak ada lagi siswa yang berjalan-jalan ke meja temannya. Secara umum siswa bisa menjawab soal pada LKS dengan benar dan lebih aktif dalam pembahasan hasil kerja dari kelomok penyaji. Persentase skor aktivitas siswa pada pertemuan ini adalah $90 \%$.

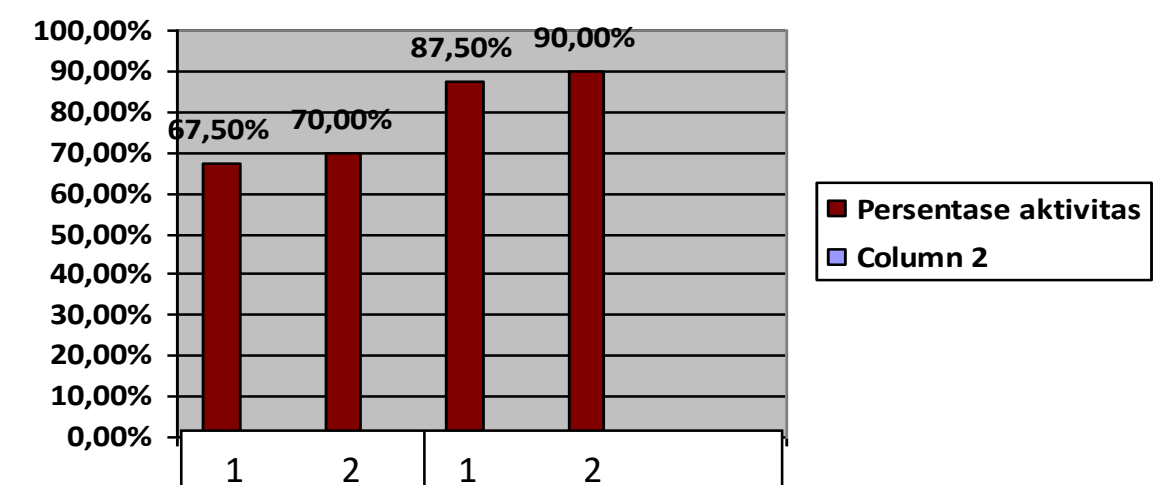




\section{Gambar 4.2 GRAFIK AKTIVITAS SISWA UNTUK PENERAPAN RME}

Terjadi peningkatan aktivitas siswa pada setiap siklus. Pada pertemuan pertama siklus I persentase aktivitas siswa adalah 67,5\%, pada pertemuan kedua siklus II meningkat 2,5\% menjadi $70 \%$. Pada pertemuan pertama siklus II meningkat $17,5 \%$ menjadi $87,5 \%$. Pada pertemuan kedua siklus II aktivitas siswa meningkat $2,5 \%$ menjadi $90 \%$.

\section{Ketercapaian Indikator}

Hasil belajar siswa bahwa terjadi peningkatan rata- rata nilai siswa, yaitu pada skor dasar rataratanya 69,2 meningkat sebesar 22,9 dengan persentase peningkatan 33,09\% pada siklus I menjadi 92,1 dan meningkat lagi sebesar 3,8 dengan persentase 4,1\% menjadi 95,9 pada siklus II. Peningkatan itu juga terjadi pada nilai minimum siswa, yaitu pada skor dasar nilai minimum siswa adalah 32 menjadi 48 pada siklus I dan pada siklus II menjadi 77. Sedangkan pada nilai maksimum siswa tidak terjadi peningkatan pada skor dasar, siklus I dan siklus II yaitu 100.

Peningkatan dari skor dasar, siklus I dan siklus II dapat dilihat pada grafik berikut ini:

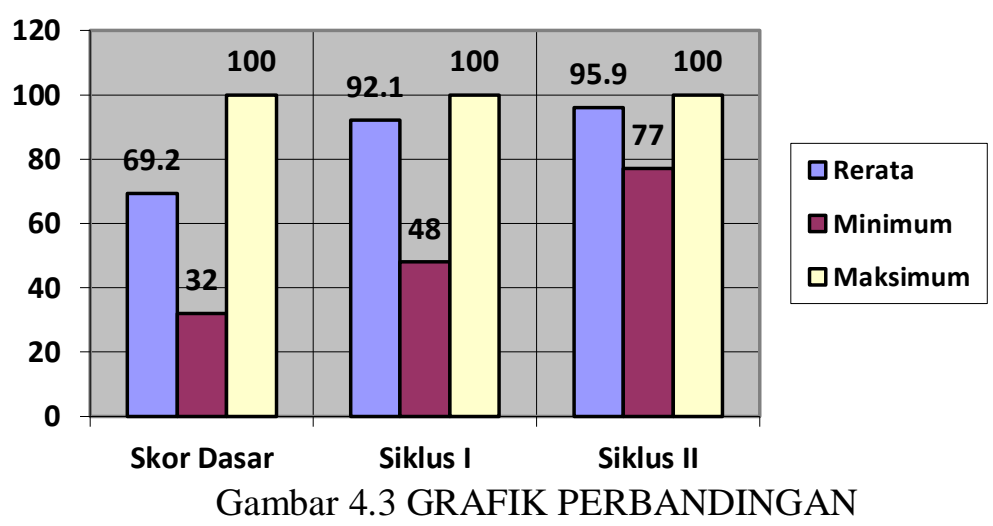

\section{Ketuntasan Klasikal Penerapan Pendekatan Pendidikan Matematika Realistik}

Grafik ketuntasan klasikal penerapan pendidikan matematika realistik dapat dilihat pada gambar berikut:

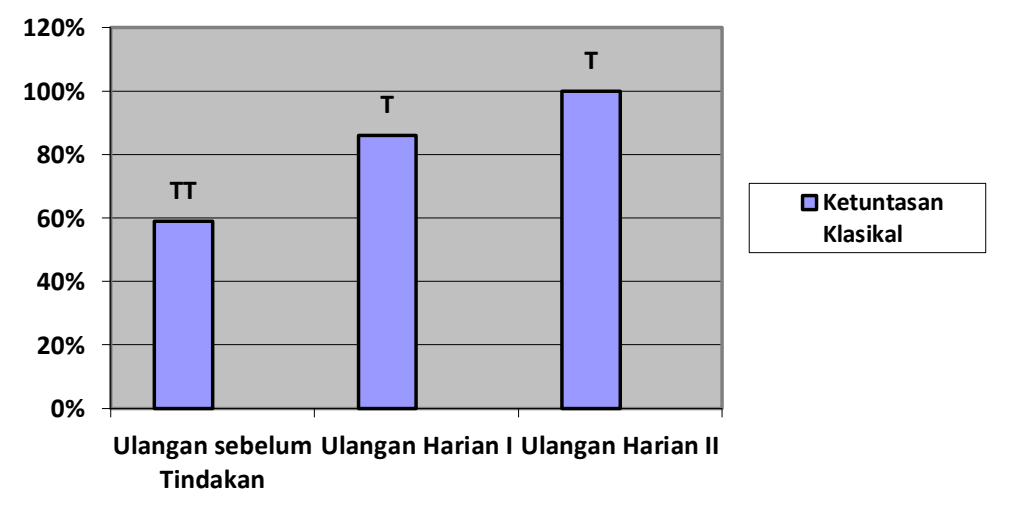




\section{Gambar 4.4 GRAFIK KETUNTASAN KLASIKAL PENERAPAN RME}

Berdasarkan grafik di atas, bisa dilihat bahwa secara klasikal terjadi peningkatan ketuntasan dari skor dasar, siklus I dan Siklus II. Pada Skor Dasar kelas tidak mencapai ketuntasan klasikal yang ditetapkan sekolah yaitu 77\%. Pada siklus I dan siklus II, kelas mencapai ketuntasan klasikal yang di tetapkan.

\section{DAFTAR PUSTAKA}

Astuti, Astuti. Pengaruh Model Pembelajaran Kooperatif Tipe Two Stay Two Stray (Tsts) Terhadap Hasil Belajar Matematika Siswa Kelas Vii Smp Negeri 2 Bangkinang Kota. Jurnal Cendekia : Jurnal Pendidikan Matematika, [S.L.], N. 2, P. 11-28, Oct. 2016. Issn 2579-9258.

Aisyah, Nyimas, dkk. 2007. Pengembangan Pembelajaran Matematika SD. Jakarta : Direktorat Jenderal Pendidikan Tinggi Departemen Pendidikan Nasional

Arikunto, Suharsimi. 2010. Dasar-Dasar Evaluasi Pendidikan.Jakarta: Bumi Aksara

Arikunto, Suharsimi. 2005. Manajemen Penelitian. Jakarta: Rineka Cipta.

Arikunto,Suharsimi, dkk Tt. 2006. Penelitian Pendidikan Kelas. Jakarta : Bumi Aksara.

Djamarah, Syaiful Bahri. 2008. Psikologi Pendidikan. Jakarta : PT. Rineka Cipta.

Daryanto. 2010. Evaluasi Pendidikan. Jakarta : Rineka Cipta.

Gravemeijer, K. 1994. Developing Realistic Mathematics Education. Trech : CD Press.

Hamalik. 2003. Proses Belajar Mengajar. Jakarta : PT. Bumi Aksara.

Purwanto, M. Ngalim. 2007. Prinsip-Prinsip dan Teknik Evaluasi Pengajaran. Bandung : PT. Remaja Rosdakarya.

Ruseffendi, ET. 1988. Pengantar Kepada Membantu Guru Mengembangkan Kompetensinya dalam Pengajaran Matematika untuk Meningkatkan CBSA Bandung: Tarsito..

Sudjana, Nana. 2003. Penilaian Hasil Proses Belajar Mengajar. Bandung : R Rosdakarya

Syahrifuddin,dkk. 2009. Psikologi Pendidikan. Pekanbaru: Cendikia Insani

Syahrifuddin,dkk. 2011. Bahan Ajar Penelitian Tindakan Kelas. Pekanbaru: Cendikia Insani

Slameto. 2010. Belajar dan Faktor-Faktor Mempengaruhinya. Jakarta : Renika Cipta.

Sulistyowati, Sofchah. 2001. Cara Belajar Yang Efektif dan Efisien. Pekalongan: Cinta Ilmu Pekalongan

Sutikno, Sobry, M.. 2007. Menggagas Pembelajaran Efektif dan Bermakna. Mataram : NTP Press

Sudjana, Nana. 2005. Penilaian Hasil Proses Belajar Mengajar, Bandung: PT. Remaja Rosdikarya.

Sudjana, Nana. 2002. Penilaian Hasil Proses Belajar Mengajar. Bandung: Remaja Rosdakarya.

Uno, H. 2011. Model-Model Pembelajaran. Jakarta : Bumi Aksara. 
Zulfah, Zulfah. Pengaruh Penerapan Model Pembelajaran Kooperatif Tipe Think Pair Share Dengan Pendekatan Heuristik Terhadap Kemampuan Pemecahan Masalah Matematis Siswa Mts Negeri Naumbai Kecamatan Kampar.Jurnal Cendekia : Jurnal Pendidikan Matematika, [S.L.], N. 2, P. 65-76, Mar. 2018. Issn 2579-9258.

Zulfah, Zulfah. Analisis Kesalahan Peserta Didik Pada Materi Persamaan Linear Dua Variabel Di Kelas Viii Mts Negeri Sungai Tonang. Jurnal Cendekia : Jurnal Pendidikan Matematika, [S.L.], V. 1, N. 1, P. 1-5, May 2017. Issn 2579-9258. 